\title{
How Do You Solve a Problem Like Juul?
}

\author{
JOSHUA M. SHARFSTEIN
}

HAT SOUND YOU DO NOT HEAR IS A TEENAGER QUIETLY TAKING
a drag from the new e-cigarette Juul — a product as loaded in
nicotine as it is popular among US youth. With a design evoking comparisons to a computer thumb drive and flavors that range from cool mint to mango, Juul is threatening to undo a decade or more of public health progress in teen smoking. The New York Times reported, "School officials, struggling to control an explosion of vaping among high school and middle school students across the country, fear that the devices are creating a new generation of nicotine addicts." 1

The danger that Juul poses to public health is made clear by a recent report from the National Academies of Science, Engineering, and Medicine, which evaluated the potential benefits and harms of ecigarettes. ${ }^{2}$ On the one hand, the committee found evidence suggesting that "e-cigarette aerosol contains fewer numbers and lower levels of toxicants than smoke from combustible tobacco cigarettes" with "limited evidence that e-cigarettes may be effective aids to promote smoking cessation." On the other hand, the report found "substantial evidence that e-cigarette use increases the risk of ever using combustible tobacco cigarettes among youth and young adults" and "moderate evidence that e-cigarette use increases the frequency and intensity of subsequent combustible tobacco cigarette smoking." The committee's models indicated it is an open question whether, on balance, e-cigarettes will turn out to undermine or advance public health. The answer may well depend in large part on the extent to which they-like Juul-are attractive to youth.

Juul is also threatening US Food and Drug Administration (FDA) plans to save millions of lives by lowering nicotine levels in combustible cigarette products while making less toxic forms of nicotine accessible to former smokers. This strategy depends on fewer kids becoming addicted to nicotine each year. It is no surprise then that FDA Commissioner Scott Gottlieb recently announced warning letters to retailers and undercover

The Milbank Quarterly, Vol. 96, No. 3, 2018 (pp. 417-420)

(c) 2018 Milbank Memorial Fund. Published by Wiley Periodicals Inc. 
sting operations to address Juul's popularity among youth. He stated, "We don't yet fully understand why these products are so popular among youth ... But it's imperative that we figure it out, and fast."3

Policymakers have several options to address rising youth use of Juul, which has captured more than half of the US market for e-cigarettes.

One option is to step back and let Juul police itself. Company executives insist, "We do not want underage kids using our products. ... We are taking it extremely seriously." The company is also pledging funding for educational efforts to teach youth about the potential dangers of e-cigarette use and nicotine addiction.

If this all seems familiar, that's because the approach is a page out of the tobacco industry's playbook. Companies would much rather pay for educational efforts than rethink the design and marketing of products that are immensely popular among youth. The FDA Commissioner recently expressed frustration with the "tepid response from companies that know that a meaningful portion of their sales are being derived from kids."

A more promising option is for the FDA to use its regulatory powers to protect youth. The agency is considering adopting regulations on flavors, which are preferred by the vast majority of children and young people using tobacco products. The agency could adopt a rule to force Juul to take all flavors attractive to youth out of its products. Similarly, the FDA could identify those design features and marketing tactics that particularly attract children and forbid their use by e-cigarette manufacturers.

Such regulatory steps are important and overdue. There's still a good chance, however, that companies will try to innovate around new FDA rules, and the cycle will start anew. There can be a delay of months to years between recognizing a problem and addressing it via regulations; the delay can mean millions of kids addicted to nicotine, at risk for progressing to cigarette smoking.

There is a third option, which could be moved forward as additional regulatory controls are put into place: an economic incentive. Through legislation, Congress could mandate that each e-cigarette brand reduce youth use to a small fraction of overall sales, requiring those that fail to do so to pay a penalty. This penalty could be large enough to recover the revenues attributable to underage use. Such an approach would give companies a financial motivation to control their supply chain, rethink their packaging, and redesign their product—as well 
as consider anything and everything else necessary to reduce youth use. This approach would also generate funding both for a strong and independent campaign to deter nicotine use by youth and for renewed efforts to help people who smoke cigarettes quit.

If this idea seems a bit politically far-fetched, consider that it almost came to be for cigarettes. The year was 1998 when California Democrat Rep. Henry Waxman worked out an unusual deal with Virginia Republican Rep. Thomas Bliley. As Waxman later wrote, "Our idea was to conduct a broad survey to establish a baseline of which brands of cigarettes kids smoked and at what volume. The tobacco companies would then be required to reduce sales to kids, penalizing any brand that failed to do so with a higher tax." ${ }^{6}$ While Congressman Bliley apparently believed that "Republicans could support it because it was a market-based, rather than a regulatory, approach," Speaker Newt Gingrich apparently decided to kill the bill rather than give Democrats a legislative victory.

It's time to dust off this strategy and apply it to Juul and other ecigarettes. In fact, the approach makes even more sense today than it did 2 decades ago. That's because unlike with combustible tobacco products, there are potential benefits of the new nicotine delivery devices-for adults who quit smoking cigarettes. With the right economic incentive, those brands that maximize benefits to adults while minimizing the harms for youth will get to charge lower prices and thrive in the market. Meanwhile, those products like Juul that attract youth will face significant penalties. The political case for this approach is straightforward: Why should companies be allowed to keep the revenues that come from underage use of their products?

It's predictable, however, that e-cigarette companies will push back against this approach. They will likely claim that penalties are unfair, on the grounds that manufacturers have little control over whether youth talk about or use their products. Juul executives have already said, "all of the things you see on social media, we have absolutely nothing to do with. We actively try to take these things down. But unless there's an infringement of our intellectual property it's quite difficult." ${ }^{4}$

This response, however, ignores the reasons youth use has gone viral: the design and marketing of the products. Change the product, take out the attractive flavors, tone down the edgy marketing, and the social media explosion will die down. An economic incentive program could set the benchmark for youth use of e-cigarettes without penalty at the same 
level of youth use of nicotine patches and nicotine gum-two products sold over the counter but without attracting substantial numbers of kids.

Unlike combustible tobacco products, if appropriately regulated, ecigarettes have the potential to help save the lives of many Americans. But sacrificing a generation of youth to nicotine addiction with higher rates of cigarette smoking is not an acceptable price to pay. The answer to the challenge posed by Juul may, in part, be to reward those e-cigarette companies that can do one without the other.

\section{References}

1. Zernike K. 'I can't stop': schools struggle with vaping explosion. New York Times. April 2, 2018. https://www.nytimes.com/2018/04/ 02/health/vaping-ecigarettes-addiction-teen.html. Accessed June 13, 2018.

2. National Academies of Sciences, Engineering, and Medicine. Public Health Consequences of E-Cigarettes. Washington, DC: The National Academies Press; 2018.

3. Statement from FDA Commissioner Scott Gottlieb, MD, on new enforcement actions and a Youth Tobacco Prevention Plan to stop youth use of, and access to, JUUL and other e-cigarettes. Silver Spring, MD: US Food and Drug Administration; April 24, 2018. https://www.fda.gov/NewsEvents/Newsroom/PressAnnouncements /ucm605432.htm. Accessed June 6, 2018

4. Barshad A. The Juul is too cool. New York Times. April 7, 2018. https://www.nytimes.com/2018/04/07/style/the-juul-is-too-cool. html. Accessed June 13, 2018.

5. Remarks by Commissioner Gottlieb to the American Society of Clinical Oncology (ASCO) Annual Meeting. Silver Spring, MD: US Food and Drug Administration; June 2, 2018. https://www.fda.gov/ NewsEvents/Speeches/ucm609579.htm. Accessed June 6, 2018.

6. Waxman H. The Waxman Report: How Congress Really Works. New York: Hatchette Book Group; 2009.

Address correspondence to: Joshua M. Sharfstein, Johns Hopkins Bloomberg School of Public Health, 615 North Wolfe St, Ste W1033D, Baltimore, MD 21205 (email: Joshua.Sharfstein@jhu.edu). 